UNTAG Law Review (ULREV)

Volume 2, Issue 1, May 2018, PP 31-43

ISSN 2549-4910 (online) \& ISSN 2579-5279 (print)

http://jurnal.untagsmg.ac.id/indeks.php/ulrev/indeks

www.fakhukum.untagsmg.ac.id

\title{
MEDIATION EXISTENCE CRIMINAL PENAL SETTLEMENT
}

\author{
Erma Rusdiana \\ Lecturer at Faculty of Law, University of Trunojoyo \\ Email : ermarusdiana@ymail.com
}

\begin{abstract}
Indonesian Constitution states that all people of Indonesia are entitled to equal treatment before the law as stated in Article 28 D, paragraph 1 of the 1945 Constitution, but they are not always easily access it. The principle of justice is simple, fast and low cost can't be reached by most people. Currently, there is also a change and dynamics of complex societies and regulations in some legislation. It also has implications on the public nature of the criminal law has shifted its relative entered the private sphere with known and practiced penal mediation. Issues raised in this paper is the concept of criminal law enforcement based on the existence of pluralistic and penal mediation as an alternative solution-in the practice of the criminal settlement. Of the studies that have been done that the concept of legal pluralism is no longer emphasizes the dichotomy between the legal system of the state on the one hand with the legal system of the people folk law and religious law on the other side. That law enforcementbased pluralistic more emphasis on interaction and co-existence of the workings of the various legal systems that affect the operation of norms, processes and institutions in community. Polarization law and penal mediation mechanisms can do, as long as it is earnestly desired by all parties ( suspects and victims ), as well as to reach a wider interest, namely the maintenance of social harmony. In summary penal mediation would have positive implications philosophically that achieved justice done fast, simple and inexpensive because the parties involved are relatively small compared through the judicial process with the components of the Criminal Justice System.
\end{abstract}

Keywords : Penal, Mediation, Settlement of Criminal Cases

\section{INTRODUCTION}

State Government System adopted by the Republic of Indonesia as expressly stated that Indonesia is a country of law. It was explicitly stipulated in the Constitution of 1945, well 
before amended (Company Act of 1945) nor the amended (Article 1 (1) of the 1945 Constitution). The consequences of these provisions is that all the problems that occurred in Indonesia, including criminal matters, should be resolved in accordance with legal procedures.

Although the Indonesian Constitution clearly states that all the people of Indonesia are entitled to equal treatment before the law and is mentioned in Article $28 \mathrm{D}$, paragraph 1 of the 1945 Constitution, but they are not always easy to access, although this is a fundamental right as part of human rights. In-Law Number 48 Year 2009 concerning Judicial Authority discovered the principle that our justice system is done with the dispute resolution that is simple, fast and inexpensive. But the fact is the judicial principle is simple, fast and low cost can't be reached by the majority of society, in addition to the legal measures that make those principles are not achieved as well as the judges who are always involved with the game commercialization Position. This condition creates an attitude of apathy when it comes to the legal community.

Almost 90\% completion of the legal problems in Indonesia solved by means of informal village level although this has been ignored by a highly centralized administration for more than 30 years. Unfortunately, in dealing with questions of justice of the poor were marginalized groups, particularly religious groups and ethnic minorities, difficult to expect justice from institutions at the village level. In other words, various informal mechanisms are still in need of support and attention which often discriminatory and inconsistent with the constitutional guarantee of human rights. ${ }^{1}$

Gradually, the criminal law as part of its existence public law aims to protect the interests of society and the state to do the matching and harmonious balance between crime on the one hand actions that authorities act arbitrarily on the other. Change and community dynamics are extremely complex on the one hand while on the other side of the regulation-making legislation as a policy legislation which is partial turns out the public nature of criminal law shifted its nature because it is relatively also enters the private sphere with known and practiced mediation penal(penal mediation)as a form of settling disputes out of court. ${ }^{2}$

On the positive law of Indonesia in principle, criminal cases can't be settled out of court, although in certain cases it is possible the case out of court settlement. However, the practice of law enforcement in Indonesia often criminal cases settled out of court with the discretion of law enforcement officers, peace mechanism, traditional institutions and others. Implications of practice for settling disputes out of court during this time there was no formal legal basis, so

1 Village Justice In Indonesia (Studi kasus tentang akses terhadap keadilan, demokrasi dan pemerintahan desa), 2004, Laporan keluaran Social Development Unit, Bank Dunia di Indonesia bekerjasama dengan tim Justice for the Poor (disingkat tim Justice)

2 Lilik Mulyadi, Pengkajian Asas, Norma, Teori dan Praktik, http://pn-kepanjen.go.id /index.php?option=com_content\&task=view\&id=140, diakses 12 April 2013 
prevalent also occur a case has informally conducted a peaceful settlement through the mechanism of customary law, but still be processed according to court positive law. Consequences increasingly applied to the existence of penal mediation as an alternative to settling disputes in the field of criminal law through restitution in criminal proceedings showed that the difference between criminal and civil law is not so big and the differences may become dysfunctional. ${ }^{3}$

In the effort to enforce the law has been agreed that we not only pay attention to "criminal law" which would be enforced it is normative solely without regard to relationship with the community. Put forward by Lord Redcliffe that we can't learn the law by studying law (solely). ${ }^{4}$ So if the criminal law enforcement only based on laws / norms only, the purpose of the criminal justice system will be difficult to achieve.

The basic principles of protection, the view of justice, honor, require the selectivity of the enactment or law applicability. Barda Nawawi Arif ${ }^{5}$ citing Ted Handerich states that in the use of criminal law it should really be considered and should be as economical as possible, to the requisite criminal was truly prevent

1. Criminal it does cause an even more dangerous / harmful than the criminal would have happened if it was not in wearing

2. No other punishment that can prevent effectively with hazards / losses are smaller.

Furthermore addressed by N Moeris, that actually SPP is none other than "Crime Containment System",in the hope that not all criminal cases entered into the process. The need for selectivity and does not require any offense in the process through the SPP things that are not serious can be resolved outside of the SPP ${ }^{6}$ The SPP criminalization is not an end nor the only way to achieve the purpose of punishment, for it can be used as well way beyond the criminal law or outside the court as mediation, discretion, forgiveness, guidance and so on, especially at the level of investigation. Moreover, in certain conditions and circumstances in implementing the rule of law, law enforcement is not solely have to think about the rule of law, but in terms of the benefits, efficiency and purpose of the law should also be in mind. Therefore the implementation of mediation in each region has different shapes and patterns, depending on

3 Detlev Frehsee(Professor of Criminology and Criminal Law, University of Bielefeld, Germany), "restitution and Offender Victim Arrangement in German Criminal Law: Development and Theoretical Implication", http://wings.buffalo.edu/law/bclc/bclr.htm, dalam: Barda Nawawi Arief, Mediasi Penal Penyelesaian Perkara Diluar Pengadilan, Pustaka Magister, Semarang, 2008, p. 4-5

4 Kadri Husen, 1985, Sistem Peradilan Pidana Menurut KUHAP, (Tesis), Jakarta, Program Hukum pasca Sarjana Univ. Indonesia, p. 18

5 Barda Nawawi Arif, 1986, Penetapan Pidana Penjara Dalam perUndang-undanganDalam Usaha Penanggulangan Kejahatan,(Disertasi), UNPAD. p.70

6 Mardjono Reksodipuro, 1989, Bahan Bacaan Wajib mata Kuliah SPP Pada Program Pendidikan Pasca Sarjana Ilmu Hukum, Univ Indonesia. p.102 
the case, social, economic, cultural and legal sense of the officials / officers.

\section{PROBLEMS}

Based on the above presentation it is necessary to study how the existence of penal mediation in criminal cases based settlement practice pluralistic?

\section{Mediation Existence Criminal Penal Settlement Pluralistic Based}

Existence settlement out of court through penal mediation can be studied from a theoretical and practical aspects. Examined from the dimensions of the practice of penal mediation will be correlated with the achievement of world justice. Over time where more and today an increasing number of case volume in all forms and variations that go to trial, and consequently become a burden to the court in examining and deciding cases according the principle "justice is simple, fast and inexpensive" without compromising achievement of the goals of justice, namely legal certainty, usefulness and fairness. Do all kinds of criminal cases must be filed and resolved upfront court, or is there a particular judge actions, allowing it to be resolved through mediation penal pattern. In polarization and penal mediation mechanisms can do, as long as it is earnestly desired by all parties (suspect and victim), as well as to reach a wider interest, namely the maintenance of social harmony.

Mudzakkir forward some categorization as benchmarks and scope of the case can be settled out of court through mediation penal is as follows: ${ }^{7}$

1. Violation of criminal law is categorized to a complaint, whether the complaint has absolute and relative complaints.

2. Violations of the criminal law has a penalty as a criminal threat and offenders have to pay a fine (Article 80 of the Criminal Code).

3. Violations of the criminal law, including the category of "offense" and not "evil", which is only punishable by a fine.

4. Violation of the criminal law, including criminal acts in the field of administrative law that put the criminal sanctions as ultimum remedium.

5. Violation of criminal law is categorized as mild / mild department and law enforcement officials to use its authority to conduct discretion.

6. Violations of the ordinary criminal law that terminated or not processed to the court (deponir) by the Attorney General in accordance with its legal authority.

7 Mudzakkir,Alternative Dispute Resolution (ADR): Penyelesaian Perkara Pidana Dalam Sistem Peradilan Pidana Indonesia, makalah workshop, Jakarta, 18 Januari 2007 
7. Violation of criminal law is categorized as traditional criminal law violations are resolved through traditional institutions.

In addition to the above dimensions, the existence of the penal mediation can be assessed from the perspective of philosophical, sociological and juridical.

\section{a. Examined from a philosophical}

Perspective, the existence of the mediation penal contains the principle of the implementation of the solution "win-win" (win-win) and not end up with a situation of "lose-lose" (lost-lost) or "win-lose" (win-lost) as to be achieved by the formal justice to the achievement of justice through the legal process litigatif (law enforcement process). Through the mediation process penal justice then obtained the highest peak since the agreement of the parties involved in the criminal case is between the offender and the victim. Victims and perpetrators are expected to seek and achieve a solution as well as the best alternative to solve the case. The implication of this is that the perpetrator and the victim can file a compensation offer, agreed and negotiated between them together so that the solution reached is "win-win" (win-win). In addition, through this penal mediation would have positive implications where philosophically achieved justice done fast, simple and inexpensive because the parties involved are relatively small compared through the judicial process with the components of the Criminal Justice System.

\section{b. Studied from a sociological perspective}

This aspect-oriented Indonesian society where cultural roots community family oriented cultural values, highlighting the principle of consensus to resolve a dispute in a social system. Strictly speaking, aspects and dimensions were resolved through local wisdom dimension customary law.

Through legal history can be seen that the primordial law applies and is a reflection of the legal consciousness of the people of Indonesia are indigenous customary law. These aspects and dimensions identical to Theorie receptive of Snouck. ${ }^{8}$

For a long enough period of customary law as a legal norm, together with other social norms

8 Theori Receptie dari Snouck Hurgronje pada pokoknya menyebutkan hukum yang hidup dan berlaku dikalangan rakyat Indonesia (Bumi Putra) adalah hukum adat. Teori ini menanggapi teoriReceptio in Complexudari LWC van den Berg dan Solomon Keyzer yang pada pokoknya menyebutkan adat istiadat dan hukum sesuatu golongan (hukum) masyarakat adalah resepsi seluruhnya dari agama yang dianut oleh golongan masyarakat itu. Kemudian teori ini ditentang oleh Hazairin dengan teoriReceptio a Contrarioyang menyebutkan hukum adat adalah suatu ketentuan yang berbeda dan tidak serta merta dapat diberlakukan dengan hukum Islam sehingga keduanya harus tetap terpisah dan ketentuan hukum agama bersifat mutlak dan hukum adat baru dapat diberlakukan kalau tidak bertentangan dengan hukum agama Islam. 
and norms of Hindu religion, plays its part serves as a means of social control. ${ }^{9}$

The logical consequence as a means of social control that indigenous customary law is born, grows and develops in a social system.

The social system is a system of interaction, so a man of action, which involves a number of individuals. The human action system, as a system, composed of the number of parts, called subsystems, which are interrelated and mutually supportive. Each part or subsystem has a specific function to the system being enveloped. Talcott Parsons said there were four (4) functions which include, namely:

1. The function of adaptation (Adaptation), the adjustment to the situation and the environment. This function refers to the necessity for social systems to cope with the environment;

2. The function of goal attainment (Goal Attainment), which is the achievement of goals or objectives. Parsons thinks that an action directed towards the goal. But attention is the main concern here is not the individual's personal goal, but the common goal of the members in a social system;

3. Function integration (Integration) is to integrate or accommodate a variety of factors related to the achievement of objectives. Which consists of guaranteeing the necessary coordination between the units of the social system related to the contribution of each unit in the organization and functioning of the whole;

4. Function maintenance or latency patterns (patterns maintenance or latency) is to preserve the patterns that have been formed based on the values. ${ }^{10}$

Local knowledge of customary law as a social model of Talcott Parsons emphasis on function integration. HR Otje Salman further mentioned law geared to accommodate the entire social system. These functions include rule system (system of norms), which served to correct the behavior that deviates from the rules concerned. So the rules of social integration requires certain behaviors that embody certain roles. Thus, the rules of a frame of reference of human behavior (member of the social system). ${ }^{11}$

Local knowledge Customary law, in the view Supomo is defined as "a living law, for he embodied the feeling of real law of the people, as well as customary law is dynamic and will

9 HR Otje Salman, Kesadaran Hukum Masyarakat Terhadap Hukum Waris, PT Alumni, Bandung, 2007, p. 21

10 Doyle P. Johson,Teori Sosiologi Klasik dan Modern, PT Gramedia, Jakarta, 1985, p. 128-144

11 HR Otje Salman,Kesadaran Hukum Masyarakat...,Op. Cit, p. 45 
grow and develop in line with the development of society." The findings Supomo the starting point of the conception of thought Friedrich Carl von Savigny with madhhab history and culture of the van Vollenhoven. Therefore, the common law is dynamic and will grow and develop in line with the development of society. In the language of Friedrich Carl von Savigny, it is called Volksgeist (the soul of the nation). Volksgeist vary depending on the place and the times stated in the customs and social organization of the people. ${ }^{12}$

Almost identical to the opinion of the initiators of the legal sociology (sociology of law) Eugene Ehrlich said that,

"Thecenter of gravity of legal development of this legislation lies not in juristic nor science, nor in judicial decision, but in society it self". Eugene Ehrlich replace voksgeist term Savigny with special terms and a more rational ie legal facts(Rechtstaatsachen / fact oflaw)and the law lives in masyaraat (living law of the people). ${ }^{13}$

Dimensions indigenous customary law which is based on the natural cosmic mind, magical and religious correlate with sociological aspects of worldview and culture of Indonesian society. In social practice in Indonesian society, penal mediation institution has long been recognized and has become a tradition among others, the people of West Papua, Aceh, Bali, West Sumatra and Lampung customary law. In people of Papua for example known "burn stone culture", as a symbol of the local culture, which is used to resolve disputes or cases, including criminal cases, through the efforts of peace sake of maintaining social harmony. Thus the criminal proceedings against perpetrators of criminal acts by state officials deemed no longer necessary, because it is perceived to be damaging back social harmony that has been achieved. Moreover, the people of Aceh as Law Number 11 Year 2006 concerning Aceh Government applied and is known for the settlement to be done first through atauPeradilan Gampong Justice of Peace. ${ }^{14}$ In addition, in Aceh Qanun No. 9 of 2008 dated December 30, 2008 on the Development of Life Indigenous and Customs in particular Article 13 determines, "the settlement of disputes / disputes and customs be completed in stages", then mentioned also, that "law enforcement officials give chance that this dispute / disputes resolved first by

12 LB Curzon,Jurisprudence, Macdonald \& Evans Ltd, Playmouth, 1979, p. 155-156

13 Eugene Ehrlich,Fundamental Principles of the Sociology of Law, New York, 1936, p. 21

14 Berdasarkan UU Nomor 11 Tahun 2006 maka di Aceh penjabarannya dibuat ketentuan perundanganundangan dalam bentuk Qanun yang berhubungan dengan hukum adat seperti Qanun Aceh Nomor 9 Tahun 2008 tentang Pembinaan Kehidupan Adat dan Adat Istiadat, Qanun Aceh Nomor 10 Tahun 2008 tentang Lembaga Adat. Kemudian selain dibuat Qanun Aceh (Qanun tingkat Propinsi) terdapat juga Qanu-Qanun tingkat Kabupaten/Kota antara lain di dalam Qanun Kabupaten Aceh Tengah Nomor 10 Tahun 2002 tentang Hukum Adat Gayo. Di Aceh, pengadilan adat yang dikenal dengan istilahPengadilan Gampong atau Pengadilan Damaijuga diimplementasikan dalam Keputusan Bersama seperti di Kabupaten Aceh Tengah adanya Keputusan Bersama antara Bupati, Ketua DPRK dan Ketua MAA Kabupaten Aceh Tengah No. 373 Tahun 2008, No 320/DPRK/2008, No.Pol B/810/2008 Res Aceh Tengah dan No. 110/MAA/V/2008 
custom or other name". Similarly, in Bali, through indigenous villages pakraman applied their awig awig which is another dimension identical to settling disputes out of court through mediation penal. For example, in Article (Pawos) 66 awig awig Pakraman ground Aron Karangasem regency stated that, "the authorities resolve the case in the village is prajuru village as judges village justice is Kelihan banjar, if litigants coming from one row and bendesa if litigants all come from one village "(Sane treatment mawosin mekadi mutusang speech-ring village inggih punika prajuru village sinaggeh kerta village; ha. Kelihan banjo, pradene the mewicara sane patunggalan banjo; na. Bendesa, the mewicara sami-sami ring petunggalan indigenous villages).

\section{c. Examined From The Perspective Of Judicial}

Penal mediation in the dimensions of state law (ius constitutum) actually is not yet widely known and still remains controversial, among the parties agree and do not agree to be applied. The essential issue leads to the selection of a criminal dispute settlement patterns, associated with the domain superiority countries with indigenous communities. In addition to the above dimensions, another implication of the actual existence of penal mediation can be said to be between "no" and "no". It is said that, on the one hand because of penal mediation in the provisions of the legislation are not known in the Criminal Justice System but the level under legislation known as limited by law and its enforcement discretion partial. Then, on the other hand turns the penal mediation practices have been carried out by the Indonesian people and the settlement is carried out outside the court as through the mechanism of traditional institutions.

There are some facts and arguments that should be noted in this context why the study of the conception of the assumed existence penal mediation between "no" and "no". ${ }^{15}$

(1) Examined ditataran regulations under the law is partial and limited nature of the mediation penal stipulated in the Letter of the Chief of Police No. Pol: B / 3022 / XII / 2009 / SDEOPS 14 December 2009 on the Handling of Cases Through the Alternative Dispute Resolution (ADR) as well as Police Chief Regulation of the Republic of Indonesia Number 7 of 2008 on Basic Guidelines and Implementation Strategy Community Policing in the Implementation of Police Duties. Basically, the rules governing the handling of criminal cases through ADR to the nature of the material losses small, it was agreed by the parties, is done through the principle of consensus, do have to respect the social norms / customs and meet the principles of justice and if it is achieved through ADR culprit no longer be touched by the action another law.

15 Lilik Mulyadi, Op.cit 
(2) In the Presidential Decree No. 8 of 2002 concerning the provision of Rule of Law Guarantees to Debtor Has Completed Its obligations or Legal Action to Debtor Not Finish His task Based Shareholder Settlement Obligations. This Presidential Directive is addressed to some Ministers / Heads of Government, including the Minister of Justice and Human Rights, the Attorney General, Chief of Police and the Chairman of the Indonesian Bank Restructuring Agency. At first dictum number 4 Instruction No. 8 of 2002 states that, "in terms of providing legal certainty as referred to in paragraph 1 concerning the exemption of the debtor of the criminal aspect related directly to the program Settlement Obligations of Shareholders, which is still under investigation, investigation and / or prosecution by law enforcement agencies, the as well as performed with the criminal aspects of handling the termination process, the implementation of which is still being done in accordance with the provisions of law applicable peundang ".

(3) The practice of normative mediation penal although not regulated by statute (positive law) but the practice occurred in Indonesian society. Penal mediation practice example has been done through the Indigenous Assembly against Prof. Dr. Tamrin Amal Tamagola conducted by the National Dayak Customary Council (MADN) named Trial Dayak Maniring Tuntang Manetes Hinting Bunu between Dayak Tamrin in betang Nagnderang, Palangkaraya, Central Kalimantan, on Saturday, January 22, 2011.

(4) Were examined from Supreme Court jurisprudence perspective penal mediation through the existence of customary justice remained admit it. For example, as one example the Supreme Court Decision No. 1644 K / Pid / 1988 dated May 15, 1991 where the ratio decadent verdict mentioned that if someone is violating customary law then Head and The Leaders of Indigenous reacted adat (customary sanction) it is concerned not be filed again (a second time) as a defendant in the trial Courts State (District Court) with the same charges in violation of the law exists and imposed imprisonment under the provisions of the criminal Code (Article 5 (3) sub b of law DRT No. 1 of 1951 ) that in such circumstances the delegation of the dossier as well as the demands of the Attorney in the District Court must be declared unacceptable (niet ontvankelijk verklaard). Conclusion basis of the jurisprudence recognizes the existence of customary justice where mediation penal between the perpetrator to the victim, then impose "traditional sanctions" is performed as a restoration of balance between offenders with community customary so that the balance between the natural cosmic and non cosmic be back as usual.

(5) The first level of the judicial practice penal mediation in another form, as seen in the North Jakarta District Court-Eastern Number: 46 / Pid / 78 / UT / WAN dated June 17, 1978 which in the case of Ny. Ellya Dado, commonly abbreviated as "Mrs. Case. Elda ", the 
settlement" peace "then the action between the parties does not constitute a crime or offense that can be punished again, and thus release the accused of all charges. In another dimension, turns on when the ratio decidendi of the decision is now also used by the Supreme Court to hear the case at the level Revision Number: 107 PK / Pid / 2006 dated November 21, 2007.

Additionally, as a comparison of the penal mediation at international level has long known. In some conferences, for example the 9th Congress of the United Nations in 1995, especially that correlates with the management of criminal justice (document A/ CONF 169/6) mentioned the need for all states considering "privatizing some functions of law enforcement and justice" and "alternative dispute resolution / ADR) in the form mediation, conciliation, restitution and compensation within the criminal justice system. Later in the International Conference on Reform of the Penal Code (International Penal Reform Conference) in 1999 stated that one of the key elements of a new agenda of reformlaw of criminal(the key elements of a new agenda for penal reform)is the need to enrich the formal justice system by system or informal mechanisms by the standards of human rights(the need to enrich the formal judicial system with informal, locally based, dispute resolution mechanisms roomates meet human rights standards)which identifies nine development strategy in revision of criminal law through the development of restorative justice, alternative dispute resolution, informal justice, alternatives to custody, alternative ways of dealing with juveniles, dealing with violent crime, reducing the prison population, the proper management of Prisons and the role of civil in penal reform. Similarly, in the 10th UN Congress in 2000 (document A/ CONF. 187/4 / Rev.3), among others, that to provide protection to victims of crime, should be introduced mechanism of mediation andjustice restorative(restorative justice). Then, as a follow-up to the international meeting to encourage the emergence of an international document which correlate with restorative justice and mediation in criminal cases such as the Recommendation of the Council of Eure 1999 No. R (99) 19 on "Mediation in Penal mattres", following the EU Framework Decision 2001 on "the Stannding of Victim in Criminal Proceedings" and the UN Principles 2002 (Ecosoc Resolution 2002/12) on"Basic Principles on the Use Restorative Justice Programs in Criminal Matters ". Then, penal mediation is also known in the State Act on Austria, Germany, Belgium, France and Poland. ${ }^{16}$

16 Pasal 90 huruf g KUHAP Austria menentukan Penuntut Umum dapat mengalihkan perkara dari pengadilan apabilaterdakwa mau mengakui perbuatannya dan siap melakukan ganti rugi khususnya kompensasi atas kerusakan yang timbul atau memperbaiki akibat dari perbuatannya, dan setuju melakukan setiap kewajiban yang diperlukan yang menunjukkan keamaunnya untuk tidak mengulangi perbuatannya di masa yang akan datang.Pada Negara Belgia mediasi penal diatur dalamthe Act on Penal Mediationdanthe Guideline on Penal Mediation.Kemudian pada Negara Perancis mediasi penal diatur Pasal 41 Code of Criminal Procedure disebutkan bahwaPenuntut Umum dapat melakukan mediasi penal (dengan persetujuan korban dan pelaku) apabila hal itu dipandang merupakan suatu tindakan yang dapat memperbaiki kerugian yang diderita korban, mengakhiri kesusahan, dan membantu memperbaiki (merehabilitasi) si pelaku. Apabila mediasi tidak berhasil dilakukan, penuntutan baru dilakukan, namun apabila berhasil penuntutan dihentikan(s. 41 dan s. 412 Code of Criminal Procedure). Pada Negara Jerman pada s. 153b StPO/Strafprozessordnung apabila kasus pidana antara pelaku dan korban melalui kompensasi(Tater-Opter-Ausgleich(TOA) telah dilakukan maka penuntutan dihentikan dan di Polandia diatur dalam Pasal 23aCode of Criminal Proceduredan Peraturan Menteri Kehakiman 13 Juni 2003 tentang "Mediation proceedings in criminal matters". 


\section{CONCLUSIONS}

1. Context reconstruction on law enforcement as if it is associated with the concept of legal pluralism Griffiths is that the law is not limited to the legal system, customary law, or religious law, but later expanded to include also the normative system in the form machanism own regulatory mechanisms as introduced Moore, namely: Law is the selfregulation of a 'semi-autonomous social field'.the concept of legal pluralism is no longer emphasizes the dichotomy between the legal system of the state(statelaw)on the one hand with the legal system of the people(folklaw)and the law(religiouslaw)on the other side. That law enforcement-based pluralistic more emphasis on interaction and co-existence of the workings of the various legal systems that affect the operation of norms, processes and institutions of law in society.

2. Polarization and penal mediation mechanisms can do, as long as it is earnestly desired by all parties (suspect and victim), as well as to reach a wider interest, namely the maintenance of social harmony. On a philosophical perspective, the existence of the mediation penal contains the principle of the implementation of the solution "winwin"(win-win), from the perspective of sociological then this aspect oriented Indonesian society where cultural roots community oriented cultural values of family, put forward the principle of consensus to solve a disputes in a social system. Strictly speaking, aspects and dimensions were resolved through local wisdom dimension customary law. In the perspective of judicial, penal mediation in the provisions of the legislation are not known in the Criminal Justice System but the level under legislation known as limited by law and its enforcement discretion partial. Then, on the other hand turns the penal mediation practices have been carried out by the Indonesian people and the settlement is carried out outside the court as through the mechanism of traditional institutions. In short this penal mediation would have positive implications where philosophically achieved justice done fast, simple and inexpensive because the parties involved are relatively small compared through the judicial process with the components of the Criminal Justice System.

\section{SUGGESTION}

It is time do law enforcement can be oriented in Indonesian society where cultural roots community family oriented cultural values, highlighting the principle of consensus to resolve a dispute in a social system. Therefore settlement out of court through mediation penal need to be set explicitly in the product legislation in particular to cases that are light, small, personal nature. 


\section{REFERENCES}

Barda Nawawi Arief, 2008, Penal Mediation Case Out of Court Settlement, Master Reader, Semarang.

Barda Nawawi Arief, 1986, Determination of Criminal Prison in legislation Relief Efforts in the Context of Crime, (Dissertation), Ubuntu.

Curzon, 1979, Jurisprudence, Macdonald \& Evans Ltd, Playmouth

Doyle P. Johnson, 1985, Classical Sociological Theory and Modern, PT Gramedia, Jakarta, Eugene Ehrlich, 1936, Fundamental Principles of the Sociology of Law, New York

Joeni Arianto Kurniawan, Recognition and Protection of Indigenous Peoples in the existence of the State Framework Law Indonesia: A Utopian Conception ? Presented papers at the Conference of State of Law, Jakarta, 9-10 October 2012

Kadri Husen, 1985, The Criminal Justice system According to the Criminal Procedure Code, (Thesis), Jakarta, post Graduate Law Program Univ. Indonesia

Lawrence M, Friedman, 1977, Law and Society: An Introduction, New Jersey: Prentice Hall Inc.

Lawrence M, Friedman, 1984, The American Law: An Invalueable Guide To The Many Faces Of The Law, And How It Affects Our Daily Lives, New York: WW Norton \& Company.

Lilik Mulyadi, Assessment Principles, Norms, Theory and Practice, http://pnkepanjen.go.id/index.php?option=com_content\&task=view\&id=140, accessed 12 April 2013

Mardjono Reksodipuro, 1989, Eye Mandatory Reading Materials Lecture SPP In Education Program Postgraduate Legal Studies, Univ Indonesia.

Max Weber in AAG Peters and Koesriani Siswosoebroto, 1988, Law and Social Development (Book I), Jakarta: Sinar Harapan.

Mochtar Kusumaatmadja, 1986, The Functions And Development Of Law In Development, Bandung: Binacipta

Mudzakkir, Alternative Dispute Resolution (ADR): Settlement of Criminal Cases in the Criminal Justice System Indonesia, a paper workshop, Jakarta, January 18th, 2007

Otje Salman, 2007, The Legal Awareness Society Against Inheritance, PT Alumni, Bandung 
Ridwan Syahrani, 1999, Summary Highlights Legal Studies, PT image of Aditya devotion, Bandung.

Roeslan Saleh, 1979, Penjabaran Pancasila dan UUD 1945 Dalam Perundang-undangan, Jakarta: Bina Aksara

Roger Cotterrell, 1984, The Sociology of Law An Introduction, London: Butterworths

Roscoe Pound, 1989, Pengantar Filsafat Hukum, Jakarta: Bhratara

Satjipto Rahardjo, 1983, Masalah Penegakan Hukum, Bandung: Sinar Baru

Soerjono Soekanto, 1983, Faktor-Faktor yang Mempengaruhi Penegakan Hukum, Jakarta: Rajawali

Sunaryati Hartono, 1991, Politik Hukum Menuju Satu Sistem Hukum Nasional, Bandung : Alumni

Theo Huijbers, 1991, Filsafat Hukum, Yogyakarta: Kanisius. 